\title{
POSSIBILITIES OF PREDICTING THE BEHAVIOUR OF FERRITE-AUSTENITE WELDED JOINTS IN PRESSURE EQUIPMENT DURING EXPLOITATION
}

\author{
Radomir Jovičić, Simon Sedmak, Ivan Samardžić, Aleksandar Sedmak, Uroš Tatić, Miloš Milošević
}

Original scientific paper

Exploitation safety of pressure equipment depends, among other factors, on the possibility of predicting the behaviour of each of its components during exploitation. If the safety of analysis is oriented towards materials which are used for manufacturing of individual parts of pressure equipment, such as mantle, lids and flanges, predicting their behaviour is relatively simple since the properties of these materials are generally similar in all directions. However, predicting the behaviour of welded joints is significantly harder and less reliable, due to a number of reasons, including chemical and structural non-homogeneity, changes in wall geometry at the welded joint site, as well as residual stresses and weld forming defects. Occasionaly, different pressure equipment parts are made of different types of steel, due to optimisation, which results in heterogeneous welded joints. Because of the difference in physical and mechanical properties of these steels, their joints have their own specificities, which make predicting their behaviour during exploitation much more complicated.

Keywords: cracks; heterogeneous welded joint; pressure equipment; stresses; structural non-homogeneity

\section{Mogućnosti predviđanja ponašanja feritno-austenitnih zavarenih spojeva na tlačnoj opremi tijekom eksploatacije}

Izvorni znanstveni članak

Eksplotacijska sigurnost tlačne opreme zavisi, između ostalog, i od mogućnosti predviđanja ponašanja svakog njenog dijela toijekom eksploatacije. Ako se analiza sigurnosti odnosi na materijale od kojih su izrađeni pojedini delovi tlačne opreme, omotač, danca, prirubnice, predviđanje njihovog ponašanja je relativno jednostavno jer se radi o materijalima čija su svojstva uglavnom ujednačena u svim smjerovima. Međutim, predviđanje ponašanja zavarenih spojeva je, zbog kemijske i strukturne nehomogenosti, promjene geometrije stijenke na mjestu zavarenog spoja, zbog zaostalih naprezanja i grešaka formiranja šava, teže i time i manje pouzdano. Ponekad se, zbog optimizacije, različiti dijelovi tlačne opreme izrađuju od različitih vrsta čelika, zbog čega se pojavljuju zavareni spojevi između raznorodnih čelika. Zbog razlika u fizikalnim i mehaničkim svojstvima ovih čelika, njihovi spojevi imaju svoje specifičnosti koje u znatnoj mjeri otežavaju predviđanje njihovog ponašanja tijekom eksploatacije tlačne opreme.

Ključne riječi: tlačna oprema; heterogeni zavareni spoj; strukturna nehomogenost; naprezanja; pukotine

\section{Introduction}

Nowadays, it can be said with great certainty that the safety of pressure equipment during exploitation is on a very high level. If this safety is assessed as the ratio of failures during exploitation to the total number of vessels in exploitation, then the risk of failure is reduced to $10^{-6}$ per year of exploitation [1], which confirms that exploitation safety is on a high level. However, pressure equipment failure still represents a significant practical problem. Many examples of pressure equipment failures are known from practice: failure of a chlorine tank in a drinking water disinfecting facility [2], leakage of several spherical tanks [3], explosion of an amin adsorber in an oil refinery [4], explosion of an autotank used for transporting of ammonia [5]. In all of the cases mentioned above, failure occurred due to welded joint fracture. Predicting of welded joint behaviour during exploitation of pressure equipment is a more complex problem, compared to the prediction of behaviour of parent materials (PM), since welded joints represent structurally non-homogeneous materials, which contain a greater number of defects than the PM and because the stress state in welded joints is much more complex than that in the PM.

For the purpose of manufacturing pressure equipment, various types of steel are used, such as low carbon, low-alloyed and high-alloyed steels [6]. Each of these types of steel is specific in its own way when it comes to welding technology and welded joint properties $[7 \div 11]$. Pressure equipment with parts made of different steels is commonly encountered in practice. Since such pressure equipment contains the so-called heterogeneous welded joints, i.e. welded joints between different types of steel, e.g. between low-alloyed and high-alloyed steel. Due to differences in physical and mechanical properties of these steels, heterogeneous joints are significantly more different than homogeneous ones $[12 \div 16]$, which additionaly complicates the prediction of their behaviour during the exploitation of pressure equipment.

\section{Cracks in a welded joint in a tank connector}

During exploitation tests of a horizontal, cylindrical, heat isolated tank for storing of liquid carbon-dioxide, a number of cracks were detected near a welded joint in one of the lid connectors [17]. Cracks are shown in Fig. 1.

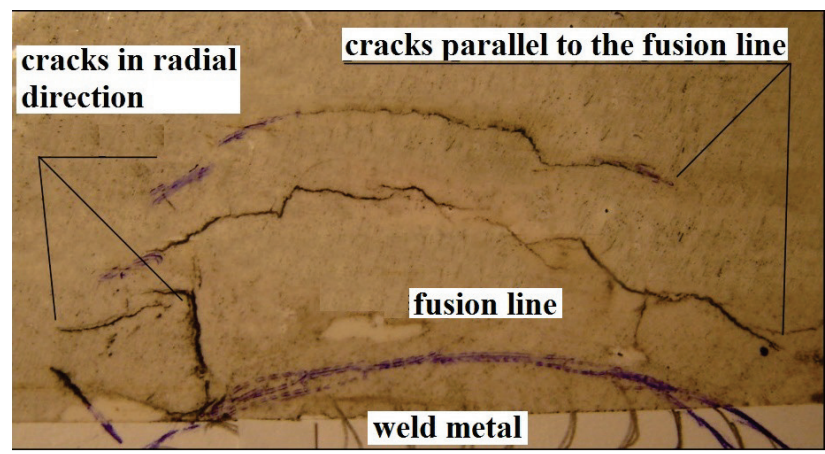

Figure 1 Welded joint cracks imprint near a connector

The diameter of the tank was $1600 \mathrm{~mm}$, and its volume was $12,5 \mathrm{~m}^{3}$ [18]. Tank mantle and lids were made of microalloyed steel P460NL1, with a thickness of 
$14 \mathrm{~mm}$, wherein the connector was made of high-alloyed austenite steel X6CrNiMoTi 1712 2. The lowest working temperature of the tank is $-55{ }^{\circ} \mathrm{C}$, the highest working pressure is 30 bar, whereas the test pressure is 39 bar. Shown in Fig. 2 is the cross-section through the connector and its welded joint. Due to considerable difference in the thickness of connector pipes $(2,9 \mathrm{~mm})$ and the lid, the welded joint was made with $10 \mathrm{~mm}$ reinforcement. According to the literature [18], the joint was welded using the E procedure, with high-alloyed austenite rutile coated wire INOX 29/9 (E 299 R 12 according to EN ISO 3581-A).

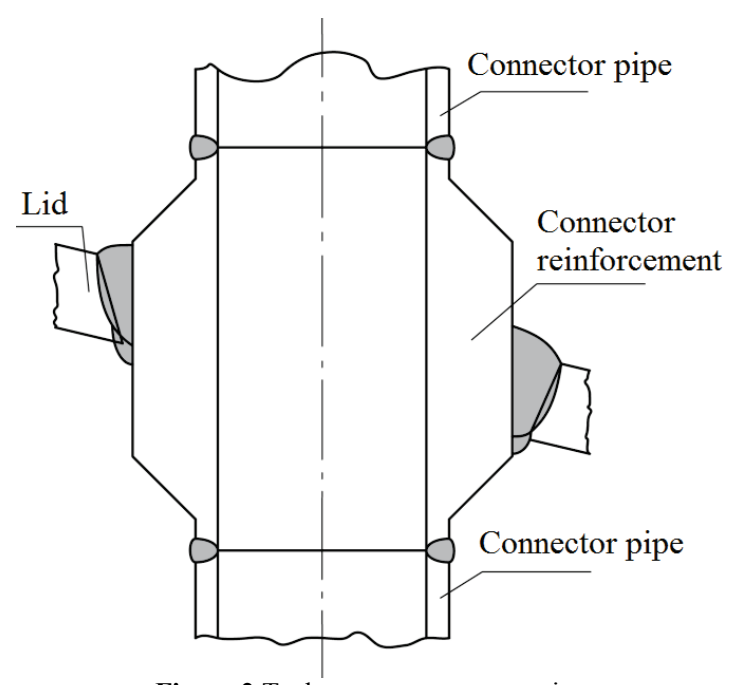

Figure 2 Tank connector cross-section

Cracks were detected via magnetic particle testing and ultrasound, prior to inner pressure testing of the tank [17]. Shown in Fig. 1 is the impring of cracks obtained by using black magnetic powder. In the figure, three cracks parallel to the fusion line (FL) can be seen, along with three cracks perpendicular to it. Lengths of cracks parallel to the FL are 60, 46 and $9 \mathrm{~mm}$. From the figure, it can be seen that the crack with a length of $60 \mathrm{~mm}$ is actually made of four cracks. Lengths of cracks perpendicular to the FL are 10, 9 and $5 \mathrm{~mm}$. Ultrasound testing determined that the maximum depth of cracks parallel to the FL was $3,5 \mathrm{~mm}$, and that the maximum depth of cracks perpendicular to the FL was $6,5 \mathrm{~mm}$. Based on the dimensions of cracks perpendicular to the FL, it can be concluded from figure 1 that cracks parallel to the FL are located far from the HAZ of the joint, i.e. that they are within the lid PM. Visual examination revealed that the width of the connector welded joint is too large for the given lid thickness.

\section{The experiment and rest results}

In order to understand the reasons behind the occurrence of these cracks, experimental tests have been conducted [12]. During these tests, the parent material (PM) and additional materials (AM), as well as the same welding procedure used were the same as in the case of manufacturing of the connector. However, deviations from the geometry of the connector welded joint were inevitable, since such geometry does not allow the making of specimens with standard shape and size.

For the welded joint, two plates with dimensions of $200 \times 500 \mathrm{~mm}$ were used, one made of micro-alloyed steel P460NL1, with a thickness of $14 \mathrm{~mm}$ (steel M) and the other made of high-alloyed austenite steel X6CrNiMoTi 1712 2, with a thickness of $12 \mathrm{~mm}$ (steel V). Chemical composition of the above mentioned steels is given in Tab. 1, whereas their mechanical properties are shown in Tab. 2. Micro-structures of these steels are shown in Fig. 3. From Fig. 3a), it can be seen that steel M has a homogeneous fine-grain ferrite-pearlite structure, whereas from Fig. 3b), it can be seen that steel $\mathrm{V}$ has an austenitic structure.

Hardness for both PM was determined using Vickers method, with a load of $100 \mathrm{~N}(15 \mathrm{~s})$. For steel M, hardness ranged from 187 to $193 \mathrm{HV} 10$, and for steel $\mathrm{V}$, it was between 193 and 227 HV10.

Test plate was welded using the E procedure, on a Kemppi Master 2500 AC/DC device. Welding was performed in a half- $\mathrm{V}$ groove. Austenite rutile coated wires INOX 29/9 with diameters of 2,5 and 3,25 mm were used, which were previously dried at a temperature of 300 ${ }^{\circ} \mathrm{C}$ over a 2 hours period. As in the case of the tank, root pass was welded from the outer side of the groove, and following this, root defects and slag were removed from the inner side by grinding. After that, welded passes were filled with alternating removal of defects via grinding. Preheating temperature was determined according to Itto Bessyio method [19], as $200{ }^{\circ} \mathrm{C}$. Welding was performed in seven passes, while the interpass temperature was maintained within a range of $190 \div 210{ }^{\circ} \mathrm{C}$. Average energy input during welding was $0,77 \mathrm{~kJ} / \mathrm{mm}$.

Table 1 Chemical composition of parent materials

\begin{tabular}{|c|c|c|c|c|c|c|c|c|c|c|c|c|c|}
\hline $\begin{array}{c}\text { Parent } \\
\text { materials }\end{array}$ & $\mathrm{C}$ & $\mathrm{Si}$ & $\mathrm{Mn}$ & $\mathrm{P}$ & $\mathrm{S}$ & $\mathrm{Cr}$ & $\mathrm{Ni}$ & $\mathrm{Cu}$ & $\mathrm{Al}$ & $\mathrm{Mo}$ & $\mathrm{Ti}$ & $\mathrm{V}$ & $\mathrm{Nb}$ \\
\hline $\mathrm{M}$ & 0,10 & 0,49 & 1,26 & 0,011 & 0,014 & 0,08 & 0,11 & 0,21 & 0,067 & 0,019 & 0,002 & 0,048 & 0,053 \\
\hline $\mathrm{V}$ & 0,04 & 0,35 & 1,73 & 0,031 & 0,004 & 17,9 & 11,6 & 0,18 & 0,061 & 2,16 & 0,38 & 0,079 & 0,016 \\
\hline
\end{tabular}

Table 2 Mechanical properties of parent materials

\begin{tabular}{|c|c|c|c|c|c|c|}
\hline $\begin{array}{c}\text { Parent } \\
\text { materials }\end{array}$ & $\begin{array}{c}\text { Upper yield stress } \\
R_{\mathrm{EH}} / \mathrm{MPa}\end{array}$ & $\begin{array}{c}\text { Lower yield stress } \\
R_{\mathrm{EL}} / \mathrm{MPa} \\
\end{array}$ & $\begin{array}{l}\text { Yield stress } \\
R_{\mathrm{p} 0,2} / \mathrm{MPa}\end{array}$ & $\begin{array}{c}\text { Tensile strength } \\
R_{\mathrm{m}} / \mathrm{MPa}\end{array}$ & $\begin{array}{c}\text { Elongation } \\
A / \%\end{array}$ & $\begin{array}{c}\text { Contraction } \\
Z / \% \\
\end{array}$ \\
\hline $\mathrm{M}$ & 453 & 435 & - & 565 & 25 & 58 \\
\hline $\mathrm{V}$ & - & - & 324 & 595 & 37 & 53 \\
\hline
\end{tabular}

Specimens were made from the welded joint and used to determine the tensile properties of the weld metal (WM) and the joint as a whole, along with their macro and micro-structures and hardness. Tensile properties of the WM were determined by testing of circular specimens $(\varnothing 6 \mathrm{~mm})$. The results of these tests are given in Tab. 3 . 


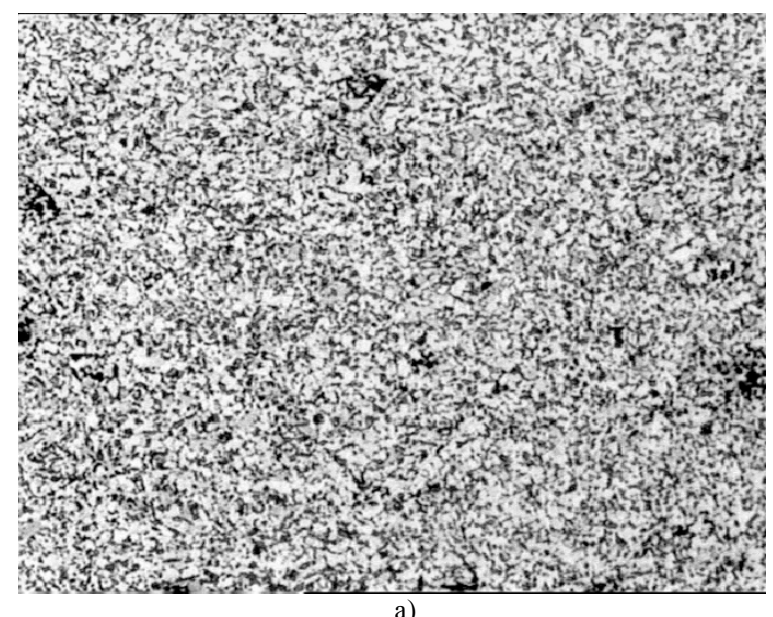

Figure 3 Parent materials, micro-structures: a) ferrite - pearlite micro-structure of steel M, b) austenite micro-structure of steel V

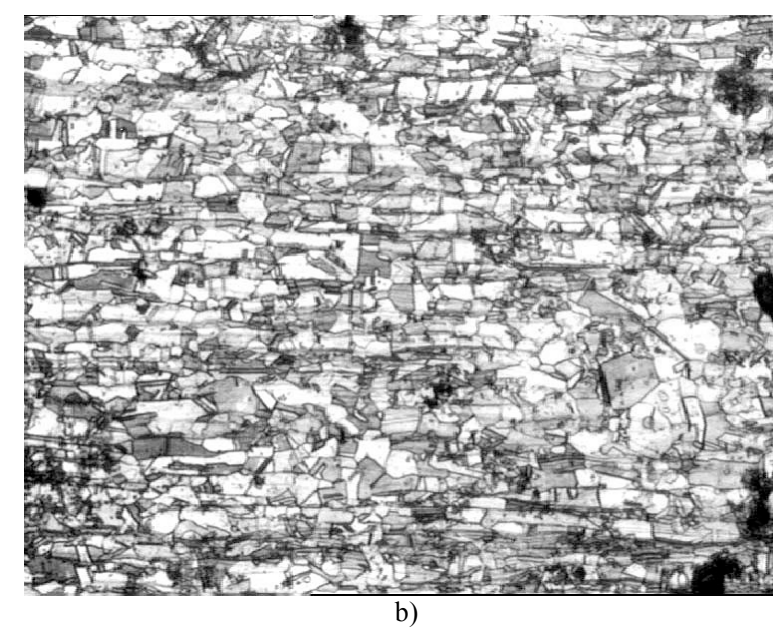

welded joint and the locations where hardness was measured.
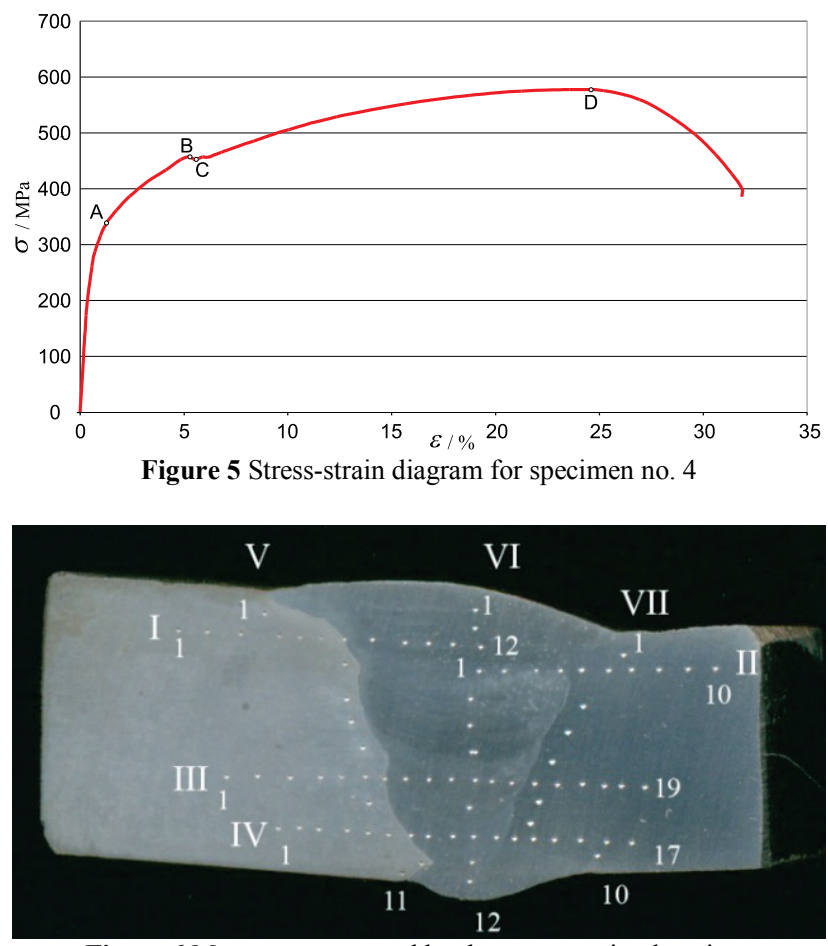

Figure 6 Macro-structure and hardness measuring locations clearly determine which of the imprints belongs to which welded joint zone. Fig. 6 shows the macro-structure of the

Table 3 Tensile properties of the weld metal

\begin{tabular}{|c|c|c|c|c|c|c|c|c|}
\hline \multirow{2}{*}{$\begin{array}{l}\text { Specimen } \\
\text { number }\end{array}$} & \multicolumn{2}{|c|}{ Yield stress $R_{\mathrm{p} 0.2} / \mathrm{MPa}$} & \multicolumn{2}{|c|}{ Tensile strength $R_{\mathrm{m}} / \mathrm{MPa}$} & \multicolumn{2}{|c|}{ Elongation $A / \%$} & \multicolumn{2}{|c|}{ Contraction $Z / \%$} \\
\hline & Individual & Mean value & Individual & Mean value & Individual & Mean value & Individual & Mean value \\
\hline 1 & 536 & \multirow{3}{*}{550} & 734 & \multirow{3}{*}{751} & 43 & \multirow{3}{*}{42} & 46 & \multirow{3}{*}{42} \\
\hline 2 & 545 & & 752 & & 42 & & 41 & \\
\hline 3 & 570 & & 768 & & 41 & & 39 & \\
\hline
\end{tabular}

Table 4 Tensile properties of specimens with the welded joint as a whole

\begin{tabular}{|c|c|c|c|c|c|c|c|c|c|c|}
\hline \multirow{2}{*}{$\begin{array}{c}\text { Specimen } \\
\text { number }\end{array}$} & \multicolumn{2}{|c|}{$\begin{array}{c}\text { Stress in point } \mathrm{A} \\
\mathrm{MPa}\end{array}$} & \multicolumn{2}{|c|}{$\begin{array}{c}\text { Stress in point B } \\
\mathrm{MPa}\end{array}$} & \multicolumn{2}{|c|}{$\begin{array}{c}\text { Stress in point } \mathrm{C} \\
\mathrm{MPa}\end{array}$} & \multicolumn{2}{|c|}{$\begin{array}{c}\text { Stress in point D } \\
\mathrm{MPa}\end{array}$} & \multicolumn{2}{|c|}{$\begin{array}{c}\text { Elongation } \\
A / \%\end{array}$} \\
\hline & Individual & Mean value & Individual & Mean value & Individual & Mean value & Individual & Mean value & Individual & Mean value \\
\hline 4 & 337 & \multirow{3}{*}{341} & 458 & \multirow{3}{*}{462} & 450 & \multirow{3}{*}{450} & 579 & \multirow{3}{*}{584} & 32 & \multirow{3}{*}{31} \\
\hline 5 & 337 & & 463 & & 450 & & 579 & & 31 & \\
\hline 6 & 350 & & 465 & & 450 & & 595 & & 31 & \\
\hline
\end{tabular}

Hardness measuring results show that the hardness of the heat affected zone of steel M $(206 \div 240 \mathrm{HV})$ is greater than that of the PM $(181 \div 202 \mathrm{HV})$, and that the highest hardness was measured in the face $(236 \mathrm{HV})$ and root $(240 \mathrm{HV})$ zones of the weld. Hardness of steel V HAZ $(187 \div 238 \mathrm{HV})$ is practically equal to the hardness of weld 
face $(221 \mathrm{HV})$ and root $(238 \mathrm{HV})$. WM hardness ranges from $236 \div 289 \mathrm{HV}$ and reach their maximum in the weld root zone $(281 \div 289 \mathrm{HV})$. WM hardness values are practically the same in the vicinity of fusion lines for both PMs.

Results of hardness measuring have shown that the hardness of steel $\mathrm{M}$ heat affected zone (HAZ), ranging between $206 \div 240 \mathrm{HV}$, was higher than the hardness of the PM $(181 \div 202 \mathrm{HV})$, and that its highest values were in the weld face $(236 \mathrm{HV})$ and root $(240 \mathrm{HV})$ zones. Hardness of steel V HAZ $(187 \div 238 \mathrm{HV})$ is practically equal to that of the PM $(187 \div 232 \mathrm{HV})$, and has the highest values in weld face $(221 \mathrm{HV})$ and root $(238 \mathrm{HV})$ zones. Weld metal hardness along the horizontal measuring lines has shown practically identical values in the vicinity of fusion lines in both PMs.

Micro-structures of the welded joint are shown in Fig. 7 , with a $\times 200$ magnification. Micro-structures of steel M and its HAZ were detected by corrosion with a $2 \%$ Nital solution. WM micro-structures were detected by corrosion with a mixture of aqua regia and pikral, whereas micro-structures of steel $\mathrm{V}$ and its HAZ were determined via corrosion with aqua regia.
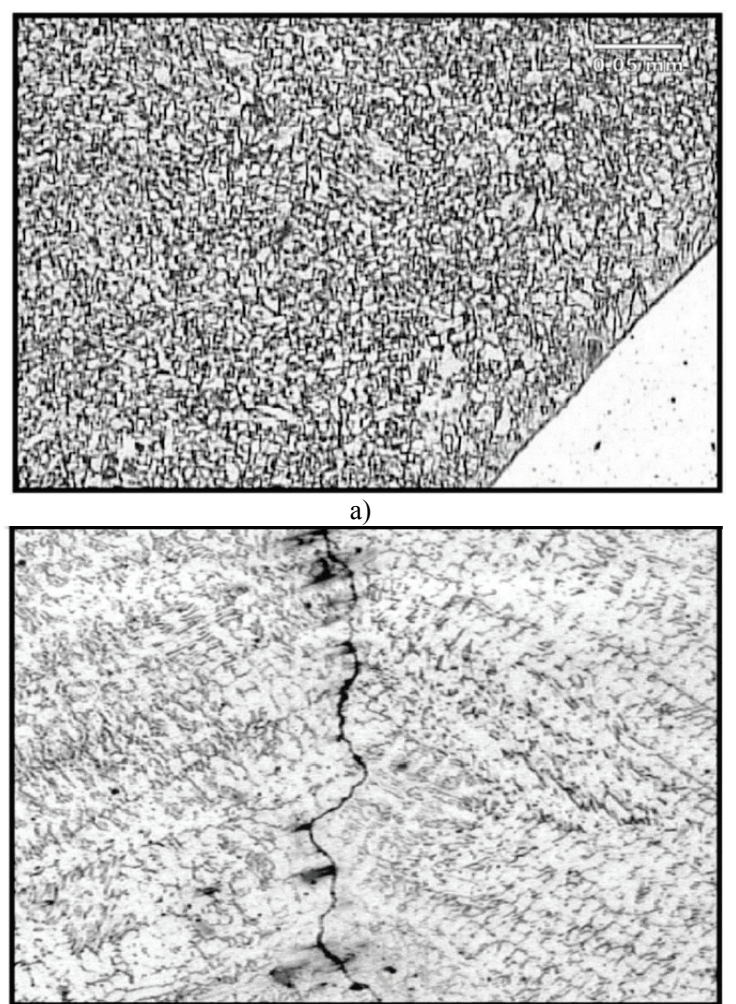

c)

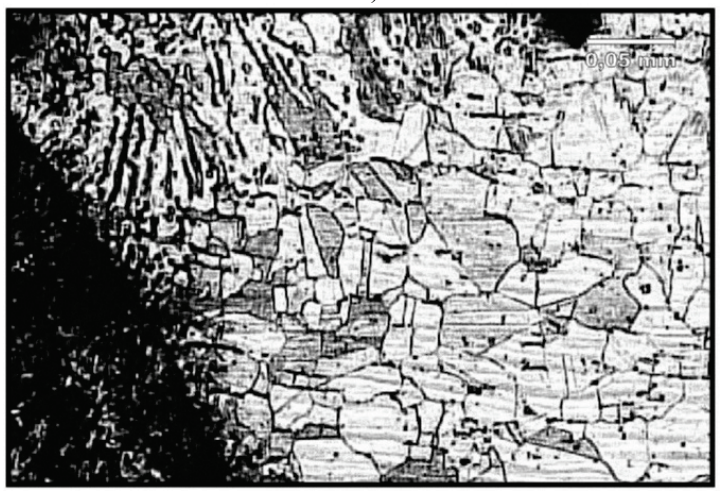

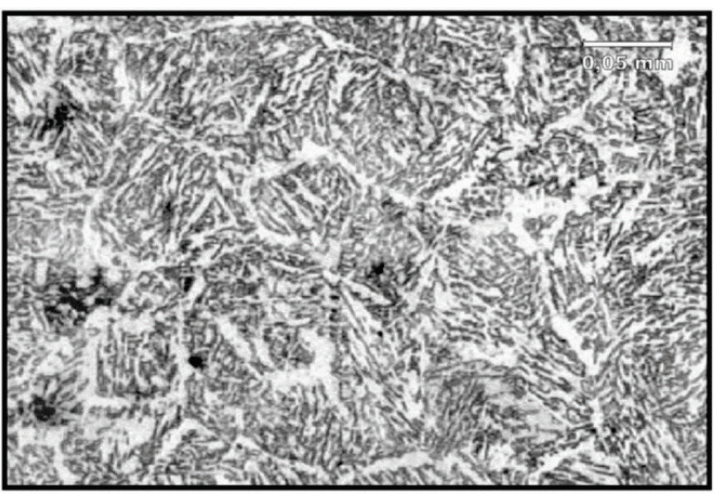

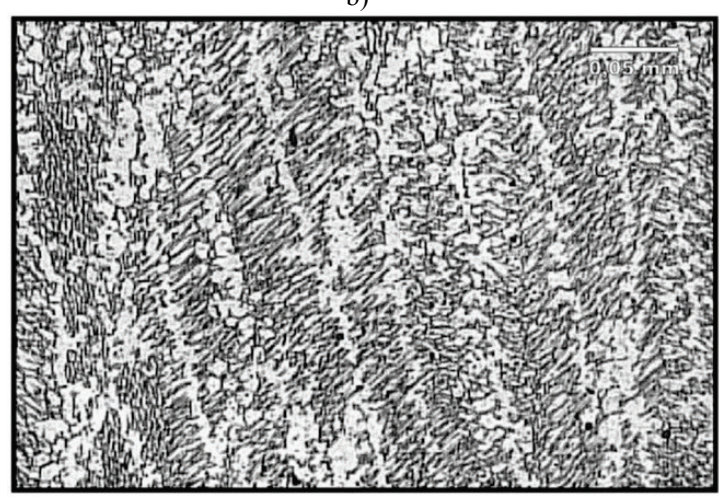

d)

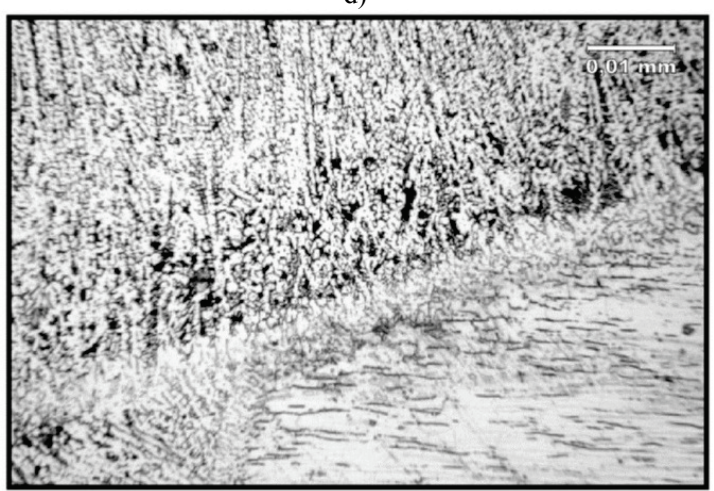

Figure 7 a) Steel M HAZ in the weld root zone; b) Steel M HAZ in the weld face zone; c) Hot crack in the root zone of the WM; d) Face zone in WM; e) $\mathrm{HAZ}$ of steel V in the weld root zone; f) HAZ of steel V in the weld face zone.

Shown in Fig. 7a) is the homogeneous fine-grain ferrite-pearlite micro-structure of the HAZ of steel $M$ in weld root zone, whereas Fig. 7b) shows the coarse-grain beinite micro-structure of the HAZ of steel $\mathrm{M}$ near the weld face. Fig. 7c) shows the fine-grain dendrite austenite micro-structure with partial $\delta$ ferrite and a hot crack near the weld root, whereas Fig. 7d) shows a coarser austenite micro-structure with more $\delta$ ferrite in the weld face zone.
Fig. 7e) shows the austenite micro-structure of HAZ of steel $\mathrm{V}$ in the weld root zone, whereas Fig. 7f) shows the austenite micro-structure of HAZ of steel $\mathrm{V}$ in the weld face zone. 


\section{Discussion}

\subsection{Cracks parallel to the fusion line}

Reasons for the occurrence of cracks parallel to the fusion line near the connector were determined based on the results of tensile tests and residual stress analysis.

By comparing the yield stress and tensile strength values of both PMs and the WM, given in tables 2 and 3, with the values in points $\mathrm{A}-\mathrm{D}$ from Tab. 4, and taking into account the shape of the diagram shown in Fig. 5, it can be assumed that point A corresponds to the yield stress of steel $\mathrm{V}$, that points $\mathrm{B}$ and $\mathrm{C}$ correspond to the upper and lower yield stresses of steel $M$, and point $D$ corresponds to the tensile strength of steel $\mathrm{V}$. Comparison of values mentioned above is given in Tab. 5. From this table, it can be observed that the values of these stresses are similar and that their deviation is within $2 \div 5 \%$.

Based on the results from Tab. 5, it was concluded tht the stress in point A correspdonds to the yield stress of steel $\mathrm{V}$, that stresses in points $\mathrm{B}$ and $\mathrm{C}$ correspond to the upper and lower yield stress of steel $\mathrm{M}$ and that stress in point $\mathrm{D}$ corresponds to the tensile strength of steel $\mathrm{V}$.

Table 5 Comparison of tensile properties of parent materials and specimens with a welded joint as a whole

\begin{tabular}{|c|c|c|c|c|c|}
\hline \hline \multicolumn{2}{|c|}{ Stress in characteristic points } & \multicolumn{2}{c|}{ Characteristic values of stress for PM } & Deviation \\
& $\begin{array}{c}\text { Mean stress value, tab. 4. } \\
\mathrm{MPa}\end{array}$ & Designation/table 2. & $\begin{array}{c}\text { Mean stress value } \\
\mathrm{MPa}\end{array}$ & $\begin{array}{c}\Delta \mathrm{R} \\
\mathrm{MPa}\end{array}$ \\
\hline \hline Designation & & 324 & 17 \\
\hline $\mathrm{R}_{\mathrm{A}}$ & 341 & $\mathrm{R}_{\mathrm{p} 0,2}$ & 453 & 9 \\
\hline $\mathrm{R}_{\mathrm{B}}$ & 462 & $\mathrm{R}_{\mathrm{EH}}$ & 435 & 15 \\
\hline $\mathrm{R}_{\mathrm{C}}$ & 450 & $\mathrm{R}_{\mathrm{EL}}$ & 5,2 & 3,0 \\
\hline $\mathrm{R}_{\mathrm{D}}$ & 584 & $\mathrm{R}_{\mathrm{m}}$ & 565 & 3,4 \\
\hline
\end{tabular}

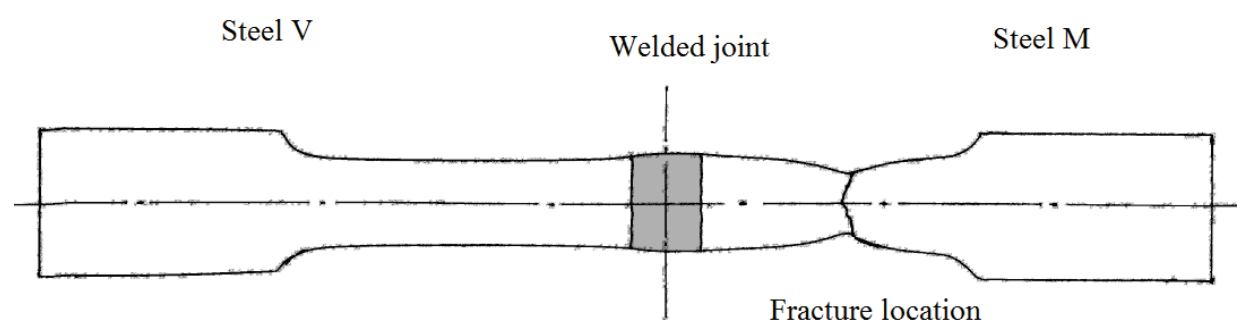

Figure 8 The shape of the specimen with a welded joint after fracture

Three speciems with a welded joint have been tested. All three specimens fractured in steel $\mathrm{M}$ parent material. Fig. 8 shows the profile of specimen no. 4 after fracture. It can be seen from the figure that fracture occurred in steel $\mathrm{M}$, away from the welded joint and that the strain along the measured part of the specimen was non-uniform.

In order to determine the strain distribution along the measured part of the specimen, cross-section contractions were measured. Fig. 9 shows the contraction distribution of the measured part of specimen no. 4. From Fig. 9, it can be seen that the contraction was lowest in the middle of the WM $(2 \%)$ and that the contraction at the fusion line with steel $\mathrm{V}(8 \%)$ was two times greater than that of the fusion line with steel M (4\%).

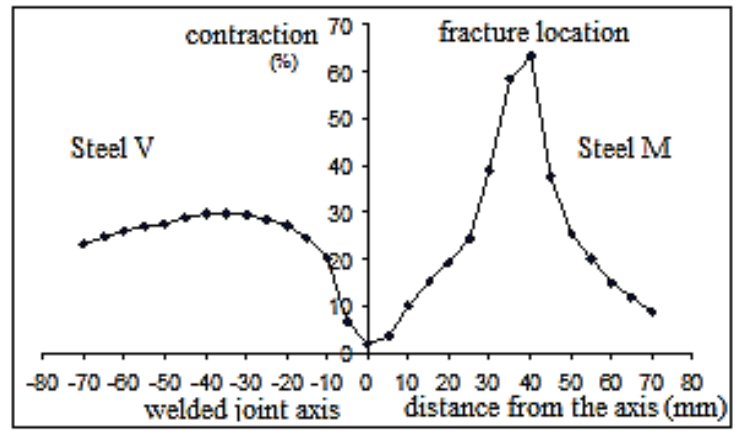

Figure 9 Cross-section contraction of the measured part of specimen no. 4

Based on the results presented, the development of strain and occurrence of fracture in steel $\mathrm{M}$ in specimens with a welded joint as a whole can be understood. During tensile testing of specimens with a welded joint, the strain develops in such a way that, until the stress in point $\mathrm{A}$ is reached (Fig. 5), there is only elastic strain in both PMs and $\mathrm{WM}$ as well. Above this stress, plastic strain starts in steel $\mathrm{V}$, whereas the strain in the WM and steel $\mathrm{M}$ is still elastic. Upon reaching the stress in point $\mathrm{B}$ in Fig. 5, plastic strain occurs in steel $\mathrm{M}$ as well. Between points $\mathrm{B}$ and $\mathrm{C}$, the stress (Fig. 5) decreases, since the stress required for plastic deforming of steel $\mathrm{M}$ is reduced. With further increase in stress, simultaneous plastic strain occurs in steels $\mathrm{M}$ and $\mathrm{V}$, wherein the WM still deforms only elastically. In point $\mathrm{D}$, the stress reaches a value that corresponds to the tensile strength of steel $\mathrm{M}$, and due to this, fracture occurs in this material. As seen from Tab. 3, yield stress of the WM is slightly lower than the stress in point D. Thus, it is expected that the plastic strain in WM should start occurring before the stress reaches the value at which fracture takes place, i.e. the WM is expected to slightly deform before fracture. It can be seen from Fig. 9 that the contraction of the middle part of the WM is only $2 \%$ which confirms the previous assumption. From the above, it can be concluded that the weakest part of this heterogeneous welded joint is steel $\mathrm{M}$, which is why the cracks near the tank connector have occurred in the lid material, further away from the welded joint.

In case of the connector welded joint, significant residual stresses are expected, as a consequence of differences in physical and mechanical properties of WM and steel $\mathrm{M}$, as well as the longitudinal and transverse contraction of the WM and a very wide weld face.

Differences in heat conductivity and linear expansion coefficients of austenite and micro-alloyed 
steels [20] result in different behaviour in terms of thermal expansion and contraction, which is why residual stresses in heterogeneous welded joints are higher than those in homogeneous ones [21]. These residual stresses are reduced due to plastic strain of materials in the welded joint [22, 23]. In this case, plastic strain in WM is disabled by its high yields stress, whereas the plastic strain of the connector is hindered by its stiffness, caused by the thickness and shape of the wall. In the case considered here, residual stresses can only be unloaded in steel $\mathrm{M}$.

Residual stresses in welded joints occur in all three directions, Fig. 10. In the case of circular welded joints, such as a connector joint, these stresses tend to reduce the circumference and diameter of the welded joint. Due to this, tensile stresses occur in the surrounding material, in radial direction. Lateral stresses lead to lateral joint contraction and tend to reduce its width. Because of this, radial tensile stresses also occur in the lid material, and are added to the stresses caused by longitudinal contraction. Lateral stresses increase with weld face width. In this case, significant lateral stresses can be expected due to larger width of the weld face, which is a consequence of the technological welding procedure applied. As was previously mentioned, root weld was welded from the outer side of the groove, and root defects were then removed from the inner groove side by grinding. During the grinding, the groove was expanded, which resulted in a wider weld face.

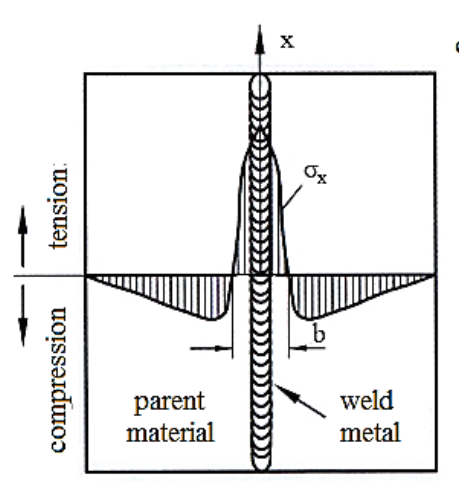

a)

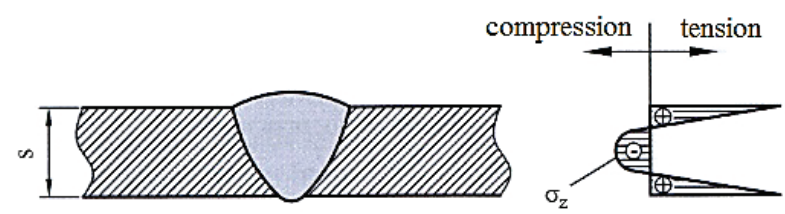

Figure 10 Residual stresses in a butt-welded joint

Considering that the cracks were detected in the lid PM, their tip propagated through a homogeneous finegrain ferrite - pearlite structure, which has high resistance to crack tip propagation. In order for the crack tip to propagate in such conditions, i.e. for the crack to grow, acting stresses must be very high. Ultrasound testing determined that the maximum crack depth was $3,5 \mathrm{~m}$, i.e. that crack growth stopped at the depth of 3,5 mm. Taking into account that an unchanged PM structure was locted in front of the crack tip, growth could only be stopped by a reduction of acting stresses. From Fig. 10c), the distribution of residual stresses along the material thickness in the welded joint can be seen [22]. Fig. 9 shows that maximum tensile stresses act on the PM surface. As the depth increases, tensile stresses rapidly decrease and become compressive at approximately one quarter of the depth. Based on the results of ultrasound tests, it can be seen that crack growth in the connector welded joint had stopped at a depth equal to $25 \%$ of lid material thickness. This confirmed the assumption that the initiation and growth of cracks parallel to the fusion line were largely influenced by residual stresses.

\subsection{Cracks perpendicular to the fusion line}

As can be seen from Fig. 1, cracks perpendicular to the FL are short, and have occurred in the HAZ of the connector joint. Ultrasound testing determined that these cracks were deeper than those parallel to the fusion line. They were characterised as cold cracks, based on their position and shape. Factors that have contributed to the occurrence of these cracks, such as stresses, structura, HAZ and WM hydrogen content cannot be taken into consideration, since the applied welding parameters (preheating temperature, interpass temperature, wire drying mode, the amount of input energy) were not known. In addition, it was not possible to conduct appropriate tests on the welded joint.

Insight into the structure and properties of the HAZ was obtained based on metallographic tests of the experimental welded joint. For the experimental joint in the $\mathrm{HAZ}$ of steel $\mathrm{M}$, it was concluded that the structure in the weld root was ferrite - pearlite, wherein the weld face zone had a beinite structure. These tests, along with hardness measuring, did not detect the occurrence of martensite in steel M HAZ. Compared to homogeneous welded joints, the occurrence of martensite structure in heterogeneous welded joints in the HAZ of steel M, where partial melting of the PM takes place, is far more likely, due to the mixing of high-alloyed AM and low-alloyed PM with relatively high carbon content. Such material is prone to annealing, even at lower cooling rates.

An austenite rutile coated wire was used for welding the connector and the experimental joint. According to data available in the literature, in the case of rutile coated wire, high hydrogen content in the WM (which may be above $12 \mathrm{ml} / 100 \mathrm{gr}$ of WM [19], or even as much as above $15 \mathrm{ml} / 100$ gr of WM [24]) should be expected. Manufacturers of coated wires recommend the drying of rutile coated wires at temperatures up to $300{ }^{\circ} \mathrm{C}$ [25]. Lower drying temperatures increase the hydrogen content in the WM. Increasing this content by $1 \mathrm{ml} / 100 \mathrm{gr}$, in the case of welding of this connector, increases the preheating temperature necessary for avoiding of crack occurrence, by $20 \div 30{ }^{\circ} \mathrm{C}$.

Practical experience has shown that prescribed interpass temperatures and in particular drying temperatures for coated wires are often ignored. As a consequence, brittle structures in the HAZ of microalloyed steels, as well as high diffused hydrogen content, occur, which leads to the appearance of cold cracks. 


\section{Conclusions}

In the case of pressure equipment, welded joints between low-alloyed ferrite - pearlite and high-alloyed austenite steels are commonly encountered. Compared to homogeneous welded joints, both low-alloyed and austenite, these heterogeneous joints are characterised by considerable structural non-homogeneity, due to two different parent materials, two different heat affected zones, and the weld metal which was different from the other parts of the welded joint.

Heterogeneous welded joints are characterised by high residual stresses, compared to homogeneous ones. Residual stress magnitude depends on the ratio of WM and PM strengths, the shape and dimensions of the welded joint and the welding procedure applied. As the difference in strength of the weld metal and parent materials and the welded joint dimensions increase, so do the residual stresses.

Heterogeneous welded joints are also likely to develop cold and hot cracks, unlike low-alloyed steels which are typically prone to cold cracks, and high-alloyed steels, in which hot cracks typically occur.

The behaviour of a heterogeneous welded joint as a whole depends on the ratio of strength and plasticity of the weld metal, both parent materials, and their heat affected zones. Predicting of heterogeneous welded joint behaviour is more reliable when based on the results of testing performed on the welded joint as a whole, compared to testing of its individual parts. Results of experimental tests presented in this paper have shown that the behaviour of individual welded joint parts depends on the properties of the material which is in contact with the observed part. If heterogeneous welded joint behaviour is based on tests of its individual parts, it is impossible to consider the mutual effects of these parts, which reduces the reliability of such predictions during pressure equipment exploitation.

\section{References}

[1] Sedmak, S. Exploitation cracks in welded joints of pressure vessels. // Monograph Exploitation cracks in welded joints of pressure vessels end tanks, Tehnološko metalurški fakultet Univerziteta u Beogradu, Goša Institut Beograd, Beograd, (1994), pp. 293-308.

[2] Elaborat broj 1390-07 o ispitivanju uzroka havarije boce za hlor f. b. 059, Zavod za zavarivanje, Beograd, 1993.

[3] Hrivnjak, I. Repair welding of large storage tanks. // Monograph Exploitation cracks in welded joints of pressure vessels end tanks, Tehnološko metalurški fakultet Univerziteta u Beogradu, Goša Institut Beograd, Beograd, (1994), pp. 328-351.

[4] MekHenri, H. I.; Rid, D. T.; Šajvz, T. R Analiza loma posude pod pritiskom - adsorbera amina. // Monografija Perspektive razvoja i primene mehanike loma, Tehnološko metalurški fakultet Univerziteta u Beogradu, Goša Institut Beograd, Beograd, (1987), pp. 187-200.

[5] Petrović, A.; Bogner, M. Posude pod pritiskom, Zavod za udžbenike, Beograd, 2003.

[6] Sedmak, S.; Nikolić, M.; Vojvodić V. Priručnik za konstruisanje procesne opreme, Tehnološko metalurški fakultet Univerziteta u Beogradu, Beograd, 1994.

[7] Folkard, E. Welding Metallurgy of Stainless Steels. // Springer Verfaf, New York, (1988), pp. 98-181. https://doi.org/10.1007/978-3-7091-8965-8

[8] Gliha, V.; Rojko, D.; Vuherer, T. Osobine zone uticaja toplote i metala šava u višeprolaznom spoju od mikrolegiranog čelika. // Zavarivanje i zavarene konstrukcije. 3(2004), pp. 103-107.

[9] Bang, K. S.; Kim, W. Y. Estimation and Prediction of HAZ Softening in Termomechanically Controlled - Rolled and Accelerated - Cooled Steel. // Welding Journal, (2002), pp. 174-179.

[10] Loureiro, A. HAZ Toughness of Multipass Welded Joints Influence of Brittle Zones. // Engineering Materials, Trans Tech Publications, Switzerland. 230-232, (2002), pp. 31-35.

[11] Adžijev, G.; Sedmak, A.; Gliha, V.; Vuherer, T. Uticaj termičkih ciklusa na žilavost ZUT mikrolegiranog čelika. // Zavarivanje i zavarene konstrukcije. 3(2007), pp. 144-147.

[12] Jovičić, R. An analysis of crack influence on integrity of ferritic - austenitic welded joints. // PhD thesis, Mašinski fakultet Univerziteta u Beogradu, Beograd, 2007.

[13] Bakić, R.; Abukresh, M.; Sedmak, A.; Samardžić, I.; Jovičić, R. Effect of Microstructure on Tensile Properties of Austenite-Ferrite Welded Joint. // Metallurgy. 54, 2(2015), pp. 335-338.

[14] Bukvić, A.; Burzić, Z.; Prokić Cvetković R.; Popović, O.; Jovičić, R. Welding technology selection effect on fracture - toughness parameters of bi-material welded joints. // Techical gazette. 19, 1(2012), pp. 167-173.

[15] Nelson, W.; Lippold, J. C.; Mills, M. J. Nature and Evolution of the Fusion Boundary in Ferritic-Austenitic Dissimilar Weld Metals. // Welding Research, Supplement to the Welding Journal, (1999), pp. 329-337.

[16] Jovičić, R.; Petronić, S.; Sedmak, S.; Tatić, U.; Jovičić, K. Integrity assessment of tanks with microcracs in welded joints. // Structural Integrity and Life. 2(2013), pp. 131-136.

[17] Izveštaj o ispitivanju u eksploataciji i sanaciji rezervoara za skladištenje tečnog ugljendioksida f. b. 1017 lociranog u pogonu "MINAKVE" u Novom Sadu, Mašinski fakultet Univerziteta u Beogradu, Beograd, (1998).

[18] Tehnička dokumentacija rezervoara za skladištenje tečnog ugljendioksida f. b. 1017, Energoinvest TPO Goražde, Goražde, (1979).

[19] Hrivnjak, I. Teorija Zvaritelnosti Kovova a Zlitin, Vydavatelstvo Slovenskej Akademie Vied, Bratislava, 1979.

[20] Schumann, H. Metalographie, VEB Deutscher Verlag fur Grundstoffindustrie, Leipzig, 1975.

[21] Granjon, H. Basses Metallurgiques du Soudage, Sudure Autogene, Paris, 1998.

[22] Sedmak, S. Uputstvo za ocenu prihvatljivosti grešaka u zavarenim konstrukcijama PD 6493. // Seminar za specijaliste za posude pod pritiskom, Tehnološko metalurški fakultet Univerziteta u Beogradu, Beograd, 1996.

[23] Vuherer, T.; Rojko, D.; Gliha, V. Uticaj reparature na nivo i raspodelu zaostalih napona u sučeonom zavarenom spoju mikrolegiranog čelika. // Zavarivanje i zavarene konstrukcije. 2(2004), pp. 61-65.

[24] EN 1011-2/2007, Welding - Recommendations for welding metallic materials - Part 2: Arc welding of ferritic steels, (2007).

[25] Catalogue of filler metal for welding, Elektrode Jesenice doo, Jesenice, 2006. 


\section{Authors' addresses}

\section{Radomir Jovičić}

University of Belgrade,

Innovation Center of Faculty of Mechanical Engineering,

Kraljice Marije 16, 11000 Belgrade, Serbia

E-mail: rjovicic@mas.bg.ac.rs

\section{Simon Sedmak}

University of Belgrade,

Innovation Center of Faculty of Mechanical Engineering,

Kraljice Marije 16, 11000 Belgrade, Serbia

E-mail: simon.sedmak@yahoo.com

\section{Ivan Samardžić}

Faculty of Mechanical Engineering in Slavonski Brod

J. J. Strossmayer University of Osijek

Trg Ivane Brkić-Mažuranić 2, Slavonski Brod, Croatia

E-mail: isamar@sfsb.hr

\section{Aleksandar Sedmak}

University of Belgrade,

Faculty of Mechanical Engineering,

Kraljice Marije 16, 11000 Belgrade, Serbia

E-mail: asedmak@mas.bg.ac.rs

\section{Uroš Tatić}

University of Belgrade,

Innovation Center of Faculty of Mechanical Engineering,

Kraljice Marije 16, 11000 Belgrade, Serbia

E-mail: taticuros@gmail.com

\section{Miloš Milošević}

University of Belgrade,

Innovation Center of Faculty of Mechanical Engineering,

Kraljice Marije 16, 11000 Belgrade, Serbia

E-mail: mmilosevic@mas.bg.ac.rs 